\title{
Interaction between felsic granitoids and mafic dykes in Bundelkhand Craton: A field, petrographic and crystal size distribution study
}

\author{
TANWita DeB* and TAPas BhatTacharyya \\ Department of Geology, University of Calcutta, 35 Ballygunge Circular Road, Kolkata 700 019, India. \\ ${ }^{*}$ Corresponding author. e-mail: tanwitadeb@gmail.com
}

MS received 14 November 2017; revised 1 February 2018; accepted 4 February 2018; published online 5 September 2018

In Bundelkhand Craton of central India, mafic dykes intruded when granitoids was partly crystallized. Cuspate-lobate boundary along the contact of granitoids and mafic magma indicates magma mingling in outcrop scale while textural evidence of mingling is represented by acicular apatite morphologies, titaniteplagioclase ocelli and ophitic--subophitic texture, mafic clots, resorbed plagioclase, and hornblende-zircon associations. Mingling also caused thermal exchange and fluid activity along the boundary between two coeval magmas. Crystal size distribution analyses for hornblende in the mafic rocks yield concave up curves which is also consistent with interaction of felsic and mafic magmas.

Keywords. Magma mingling; crystal size distribution (CSD); Bundelkhand Craton.

\section{Introduction}

Magma mixing and mingling are important processes in magmatic evolution, and its study may lead to the reconstruction of tectonic setting and paleoenvironment (Sklyarov and Fedorovsky 2006; Lai et al. 2008). Magma mixing and mingling are two different processes. The term 'mixing' is used when chemical interaction between two melts produced a homogeneous magma as end product (Vernon 1984; Neves and Vauchez 1995). The term 'mingling' is used when homogeneity had not been attained in a final rock specimen; two magmas form heterogeneous physical mixture at microscopic and mesoscopic scales (Wilcox 1999). Magma mixing and mingling depend on the contrasting magma properties, such as temperature, compositions, density, volatile content, viscosity and pressure (Winter 2010).

Effect of magma mixing/mingling is found in outcrop to microscopic scales as well as in chemical and isotopic features. Combination of several textures or 'textural assemblage' is good indicator of magma mixing/mingling (Hibbard 1991; Burda et al. 2011). Magma mixing/mingling also leads to the disequilibrium condition which influences the nucleation and growth rate of the crystals (Słaby and Götze 2004). However, crystal nucleation and growth rate do not affect the overall chemical composition. Therefore, chemical analysis by itself cannot reveal the greater picture of petrological evolution of magma affected by magma mixing/mingling. Recently crystal size distribution (CSD) analysis has become a more important technique to understand various petrological processes including magma mixing (Eberl et al. 1998; Marsh 1998; Higgins 1996, 2000; Higgins and Roberge 2007; Morgan et al. 2007).

Mafic magma intrudes into the granitic system at different stages of crystallization of felsic magma. Barbarin and Didier (1992) and Barbarin (2005) proposed a four-stage model based on 
emplacement of mafic magma at different stages of crystallization of granitoids. (i) First stage: mafic magma is introduced before the beginning of crystallization of the felsic magma, leading to the formation of homogenous hybrid magma and calalkaline granitoids. (ii) Second stage: mafic magma enters slightly later, when the felsic magma began crystallizing, magma mingling between the coexisting magmas occurred due to viscosity difference, blobs of mafic magma will form as mafic enclave in the felsic host magma. (iii) Third stage: if the mafic magma was introduced into the system when the felsic magma has partly crystallized, local interaction of mafic and last magmatic liquid would occur producing composite (or disturbed) syn-plutonic dykes. (iv) Fourth stage: late injection of mafic magma into solidified granitoids to form undisturbed mafic dykes without any mingling effect.

Many workers gave detailed petrographical and geochemical data of the mafic magmatic enclaves and host rocks studied from different areas (Frost and Mahood 1987; Baxter and Feely 2002; Barbarin 2005; Kumar 2010; Kumar et al. 2010). Mafic enclaves (also known as mafic magmatic enclaves or MME) in felsic plutons are a common phenomenon and their presence imply good evidence of mixing between mafic and felsic magmas (Pabst 1928; Vernon 1984; Frost and Mahood 1987; Barbarin and Didier 1991; Barbarin 2005). Detailed petrogenesis of the mafic magmatic enclaves (MME) including their relations with host granitoids in Bundelkhand Craton was given by Ramiz and Mondal (2017). However, syn-plutonic mafic dykes were reported from Dharwar and Bastar Craton, India (Jayananda et al. 2014; Elangovan et al. 2017), but there is a lack of publications on the interaction of such coeval mafic dykes and granitoids in Bundelkhand Craton.

In this paper, we discuss the mingling effect (in outcrop and microscopic scale) of mafic dykes which intruded the partly crystallized granitoid magma observed along the Jhansi-Shivpuri road (NH 25) near Karera and Dinara of Bundelkhand Craton. In addition to field observation and microscopical study, we have done CSD analyses for understanding the effect of mingling on nucleation and growth rate of crystals.

\section{Geological setting and sampling}

One of the major constituents of the Indian Precambrian terrain is the Bundelkhand Craton occurring in the central part of the Indian peninsula. It covers an area of $26,000 \mathrm{~km}^{2}$ (between $24.5^{\circ}-25.5^{\circ} \mathrm{N}$ and $78^{\circ}-80.5^{\circ} \mathrm{E}$ ) in southwestern Uttar Pradesh and northeastern Madhya Pradesh, India. The craton is surrounded by Ganga alluvium in the north and north-east, Vindhayan Supergroup in the west, south, and south-east and Bijawar Supergroup in the south and south-east (figure 1a). The principal rock-types of this craton are: (i) Bundelkhand greenstone complex (Malviya et al. 2006; Kumar et al. 2013; Singh and Salbunov 2015), with trondhjemitic gneisses (Sharma and Rahman 1995) which later identified as TonaliteTrondhjemite-Granodiorite (TTG) (Ram Mohan et al. 2012), metamorphosed basic and ultrabasic rocks (range in composition from basalt through basaltic-andesite to basaltic-komatiite), Banded Iron Formation (BIF), rhyolite and dacite (Basu 1986; Gupta 2004; Malviya et al. 2006); (ii) Bundelkhand granitoid massif, with some pelitic and mafic inclusions (Basu 1986; Mondal and Zainuddin 1996; Gupta 2004; Ray et al. 2015); (iii) mafic dyke swarm, mostly dolerites with subordinate pyroxenites and lamproites (Rao et al. 2005; Ramakrishnan and Vaidyanathan 2008; Pradhan et al. 2012) and (iv) quartz reef (Basu 1986; Pati et al. 2007; Bhattacharya and Singh 2013; Prakash et al. 2013).

Outcrops showing evidence of mingling present along Jhansi-Shivpuri road (NH 25) near Karera $\left(25^{\circ} 27^{\prime} 15^{\prime} \mathrm{N}, 7^{\circ} 09^{\prime} 24^{\prime \prime} \mathrm{E}\right.$ and $25^{\circ} 26^{\prime} 5^{\prime \prime} \mathrm{N}, 78^{\circ} 07^{\prime}$ $\left.59^{\prime \prime} \mathrm{E}\right)$ was studied in detail. Outcrop near Dinara $\left(25^{\circ} 28^{\prime} 24^{\prime \prime} \mathrm{N}, 78^{\circ} 20^{\prime} 39^{\prime \prime} \mathrm{E}\right)$, beside Jhansi-Shivpuri road (NH 25) also shows mingling effect. In our study area, mafic dykes intruded in granite magma during the last stage of crystallization of granitoid magma. These highly disrupted tabular bodies of mafic rocks occur within the granitoid near Karera. In the rest of the paper, they will be referred to as granitoid and mafic rocks.

In all over Bundelkhand, amphibolites often present as enclaves in granitoids. The amphibolites or mafic magmatic enclaves (MME) show unambiguous distinctions both geometrically and compositionally from the mafic dykes within the granitoids along Jhansi-Shivpuri road (NH 25). Mafic Magmatic Enclaves (MME) are only present as inclusions (a few cm long) in granitoids (including TTG) all over the Bundelkhand Craton as circular, elliptical, tabular, or irregular bodies. At places they are sheared into sigmoid shapes. These enclaves have either sharp or corroded boundary with the host rocks. They often show internal 


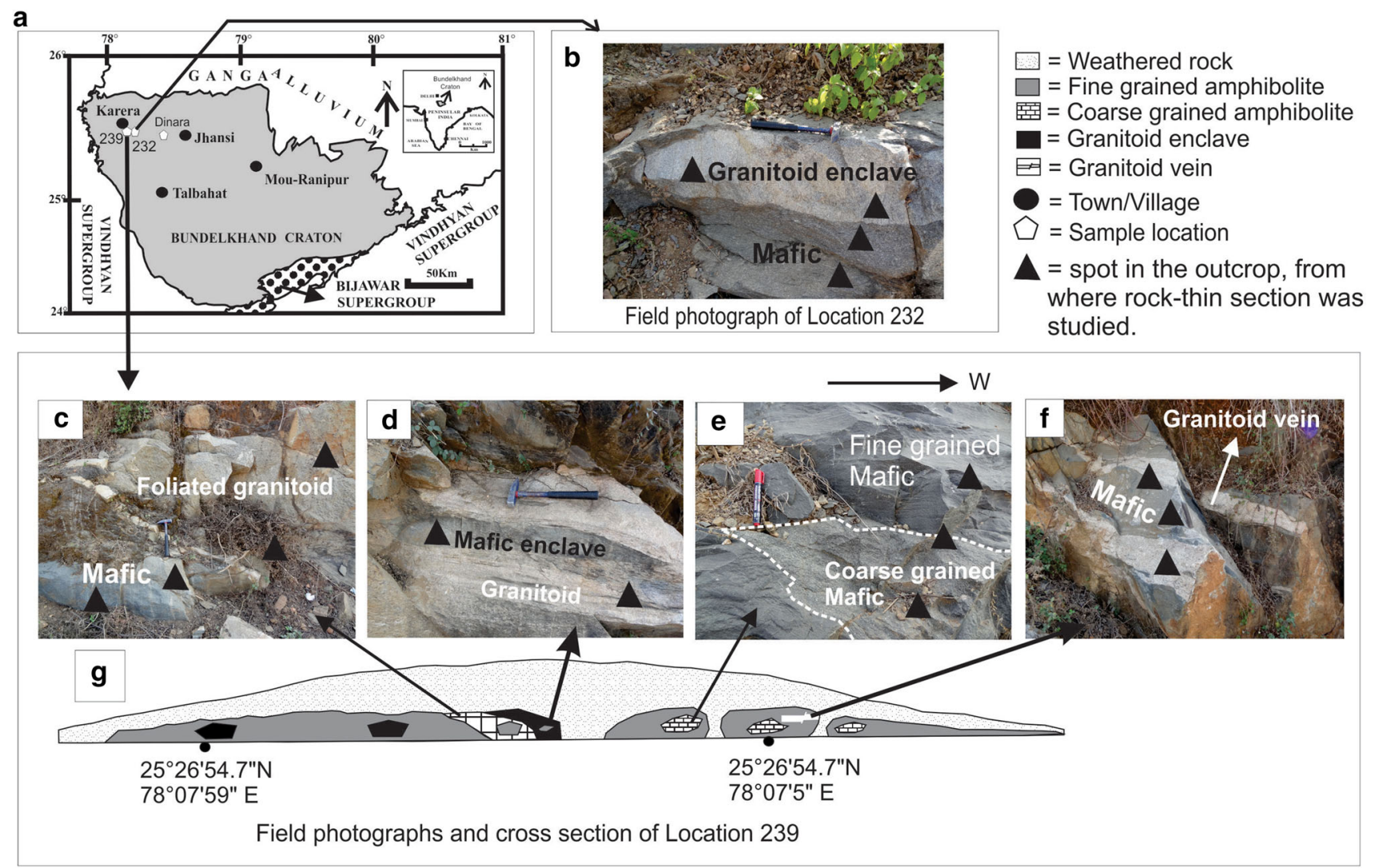

Figure 1. (a) Generalized map of Bundelkhand Craton showing the localities of magma mingling (modified after Basu 1986). (b-f) Field photographs showing the spots from where rock-thin section was studied (marked by solid black triangle). (g) Schematic diagram of road section of location 239 showing different types of magma mingling.

foliation and folding discordant to structures in the host rock. These enclaves show sub-ophitic texture, are made up of medium to fine grained pyroxene, olivine, amphibole and plagioclase as principal constituents, along with a subordinate amount of quartz and K-feldspar (Ramiz and Mondal 2017). Apatite and titanite are accessory minerals. Where foliated the foliation is marked by the preferred alignment of amphibole grains. At places alternate mafic and felsic bands are present. While mafic bodies near Karera area mainly occur as disrupted but not too widely dispersed bodies within granitoids. At places the disrupted portions can be joined by interpolation suggesting a tabular shape. Individual mafic bodies (the fragments of dyke) are up to a meter long. The mafic rock ranges from fine to coarse grained, and is composed of hornblende (90-55\% volume), and quartz+plagioclase+alkali feldspar (together 10-45\% volume), with accessory minerals like biotite, epidote, titanite, and opaque. The finer-grained variety tends to be richer in hornblende. The $\mathrm{E}-\mathrm{W}$ foliation is marked by the preferred alignment of hornblende grains.
A total of 36 samples were collected. Among which 21 samples were from granitoid, and 15 samples were from mafic dykes (figure $1 \mathrm{~b}-\mathrm{g}$ ). Only very clean and unaltered samples were collected. Twenty thin sections were made for textural analyses including CSD study.

\section{Analytical methods}

\subsection{Textural analyses}

The textures were examined under a polarized light microscope. The total measured area of different minerals and the total area of the rock in each thin section were calculated with the help of the software Image J. The total area occupied by different minerals of each sample is expressed as a percentage of the area of the thin section (cf. modal abundance or volumetric phase proportion by Higgins 2002; Jerram et al. 2003). CSD studies of hornblende were made only of the haphazardly oriented grains or clots. Small and brownish hornblende, warping the plagioclase laths were excluded 
as the individual grains mostly composite of biotite and hornblende. CSD study of the host granitoids could not be made because of lack of sufficient number of grains of the major minerals in individual thin sections.

\subsection{CSD theory and measurements}

\subsubsection{CSD theory}

Marsh (1988), and Cashman and Marsh (1988) first used crystal size distribution study. In CSD diagram, the natural logarithm of the crystal population density (i.e., number of crystals per unit volume) is plotted against the size (L) of crystal (Higgins 2000). According to Marsh (1988) in a steady state open system, CSD gives linear pattern when logarithm of the crystal population density is plotted against the size (L) of crystal. Linear regression of $\ln (n)$ vs. $\mathrm{L}$ is used to calculate the slope and intercept value. The reciprocal of the slope, where slope equals to $-1 / G \tau(G \tau=$ average growth rate of the crystal $*$ residence time), is the crystal characteristic length, and intercept value gives nucleation density (Marsh 1988; Higgins and Roberge 2007). If the growth rate is known then residence time (i.e., crystal growth time in magma chamber) can be calculated. Assuming growth rate of plagioclase is $10^{-10} \mathrm{~mm} \mathrm{~s}^{-1}$ (Cashman 1993), residential time is calculated.

\subsubsection{CSD analyses procedure}

The measurements for the CSD studies were made on photomicrographs taken by NIS-Element software from standard rock thin sections of coarse grained mafic rocks. All photomicrographs of a single thin section were pasted together to make a mosaic. In each mosaic hornblende and plagioclase grains were drawn separately and then saved as uncompressed tiff files (figure 2). Then the following parameters in each grain were measured - area, major and minor axes of best fit ellipse to the crystal outlines, its orientation and positions - by using Image $J$ software.

CSD is a volumetric measure. But we measured crystal size and numbers from thin sections which are two-dimensional. To convert this two-dimensional data into three-dimensional data we used the program CSD Correction 1.51 (version 2015) (Higgins 2000), in which corrections for both the intersection probability effect and the cut section effect have been taken into concern. This software also requires several other inputs like 2D length measurements, image area, average 3D-crystal habit, roundness, and sample foliation, and volumetric phase proportion of plagioclase. The roundness of crystals and foliation of rocks were measured by eye-estimation (table 1 ). In CSD study degree of roundness of crystals ranges from 0 to 1 (with 0 being a rectangle and 1 an ellipse) and the foliation of rocks ranges $0-1$ ( 0 for no foliation and 1 for very strong foliation). Higgins and Roberge (2007) emphasized that such values do not affect the CSD values as such. The rock used for the CSD study show foliation but foliation is not as strong as schist, so value 0.5 is used. When the 3D-crystal habits of hornblende and plagioclase in coarse grained mafic rocks were determined using the software CSD Slice (cf. Morgan and Jerram 2006) it estimated crystal habit rectangular as parallelepiped, not ellipsoid. So value is estimated close to 0 .

The 3D-crystal habits of hornblende and plagioclase in coarse grained mafic rocks were determined using the software CSD Slice (cf. Morgan and Jerram 2006). The program CSD Slice gives five possible $3 \mathrm{D}$ axial ratios (with $\mathrm{R}$ value) that would yield $2 \mathrm{D}$-curves that would best-fit the obtained curve (figure 3). The obtained curve is actually compared with similar plots obtained from random $2 \mathrm{D}$ sections of $3 \mathrm{D}$ shapes with 703 different axial ratios in the range 1:10:10 through 1:1:10 to $1: 1: 1$. Frequencies from the actual data and the frequencies from corresponding bins of the theoretical data base are plotted in an $\mathrm{X}-\mathrm{Y}$ plot, and the line with highest correlation coefficient between the observed frequency and the model frequency is chosen. Finally, software CSD Corrections 1.51 was used to generate CSD plots (Higgins 2000). Grain size-class with more than five grains was used in the CSD analyses (table 2). The frequency data were plotted on $\mathrm{X}-\mathrm{Y}$ graphs with natural logarithm of population density along Y-direction, and length in millimeter along $\mathrm{X}$-axis. In addition to intercept and slope values $(-1 / G \tau)$ CSD analyses also show goodness-of-fit $(Q)$. Q describes statistically how well the data fit to a straight line taking into account the amount of error associated with each point. A value greater than 0.1 indicates a very significant fit, but values $>0.01$ may also be acceptable (Higgins and Roberge 2007). If $Q>0.1$, then CSD may follow the model distribution. A value close to 1 may indicate that the errors have been overestimated (Higgins 2006). A strongly curved CSD have very small value of $Q$ (Higgins and Roberge 2007). 

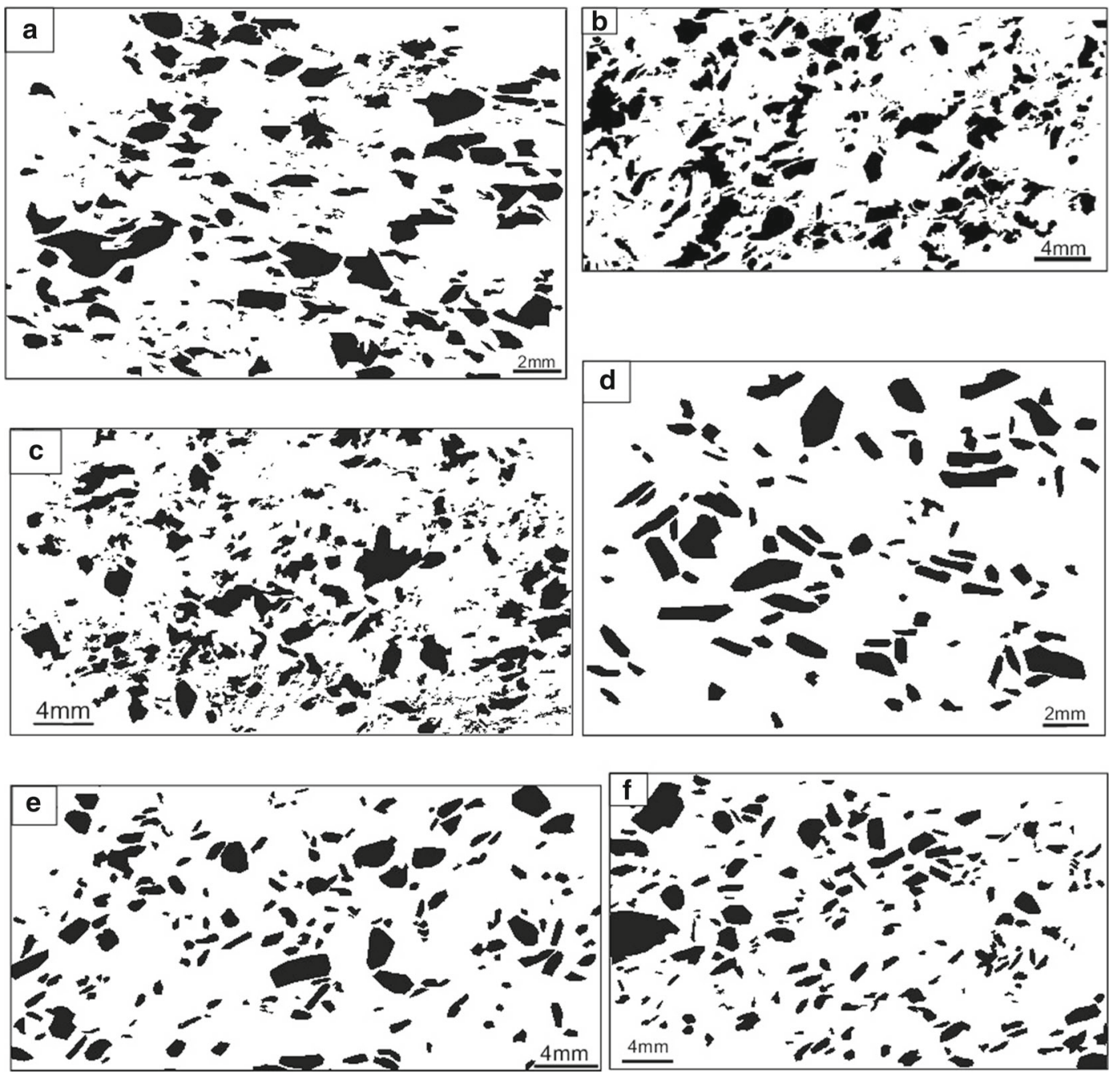

Figure 2. Digitized outlines of $(\mathbf{a}-\mathbf{c})$ green coloured haphazardly oriented hornblende grains present in coarse-grained mafic rocks. (d-f) Plagioclase present in coarse-grained mafic rocks.

\section{Mingling features seen in outcrop}

The mafic inclusions in granitoids show two different types of geometries (i) tabular fragments and (ii) a few rounded, elliptical enclaves. Tabular fragments are mainly found near Karera (figure 4a). Individual exposures of granitoids with tabular mafic fragments are a few meters long and occur in two clusters $140 \mathrm{~m}$ apart. The area between the two clusters is free from any exposures. The fragmented mafic dyke near Dinara is $\sim 5 \mathrm{~m}$ long and $\sim 1.5 \mathrm{~m}$ wide (figure $4 \mathrm{~b}$ ). It intruded medium grained massive granitoid. The individual tabular mafic bodies generally have cuspate-lobate contact with massive granitoids. Interestingly, at some places, the direction of closure of the lobes, hence the cusps, are consistently not towards only one rock type either granitoids or mafic rocks. Within a few $\mathrm{cm}$, the closure directions of the lobes change from that towards the granitoids to towards the mafic rocks (figure 4c). However, the cusps are not so sharp. Elliptical mafic enclaves within granitoids are circular to elliptical, 30-50 cm long and 10-15 cm wide (see figure $4 \mathrm{~b}$ ). The contact of enclaves with granitoids is either sharp or gradational. In addition to massive, medium grained granitoids, three other types of granitoids were observed: (i) Strongly foliated granitoids near the contact with mafic bodies. Unlike massive granitoids, it contains parallelly aligned mafic clots (figure $4 \mathrm{~d}$ ). The rock is distinguished from the main granitoids only by the presence of these mafic clots. (ii) Up to a metre long massive to weakly foliated semi-circular to elliptical bodies within mafic rocks (figure 4e). (iii) Massive to weakly foliated vein-like bodies within the mafic rocks (figure 4f). The contact of type (i) granitioid with mafic rock is either 
gradational or sharp (figure 4f). The contacts between granitoid enclaves (type ii) and mafic rocks are nearly sharp and often show cuspatelobate pattern. Granitoid veins (type iii) within mafic rocks are a few meters long and $55-65 \mathrm{~cm}$ wide with cuspate-lobate boundary.

\section{Petrography}

\subsection{Texture of mafic rocks}

Fine grained mafic rocks consist of hornblende ( $\sim 80-90 \%$ vol.), quartz, plagioclase, and alkali feldspar. Hornblende grains are aligned E-W. Titanite is an accessory. Generally lozenge or wedge shaped, titanite grains often show ophitic and subophitic texture with feldspar.

Coarse-grained variety of mafic rocks consist mainly of hornblende, plagioclase with minor amount of biotite, titanite. The hornblende grains are of two types: (i) pleochroic in shades of green, with irregular shape, variable size $(0.10-4.5 \mathrm{~mm}$ long), and occasionally with iron oxide inclusions and (ii) with yellowish green to brownish green pleochroism, and smaller in size (average $0.14 \mathrm{~mm}$ long). Many such grains show partial alteration to biotite, and some grains are composite grains of hornblende and biotite (figure 5a). These smaller grains warp around plagioclase grains. Plagioclase grains are lath shaped and randomly oriented. The plagioclase grain often shows resorbed grain boundaries and sericitization (figure 5b). This rock also contains higher amount of acicular apatite (figure 5c). The needle shaped apatites are variable in size and haphazardly oriented. Most of the titanite grains show titanite-plagioclase ocelli and ophitic and sub-ophitic texture.

\subsection{Texture of granitoids}

Under the microscope massive granitoids show hypidoimorphic texture, mainly composed of alkali feldspar, quartz, and plagioclase. Quartz grains often show undulose extinction and subgrain formation. Feldspar grains (both plagioclase and alkali feldspar) are subhedral often with resorbed boundary. Feldspars are partially to completely sericitized. Micrographic and myrmekitic texture are also found.

Foliated granitoids with mafic clots mainly consist of alkali feldspar, quartz, plagioclase feldspar, and hornblende. Hornblende grains occur 
a Best fit shape curve of amphibolite (239/3A/1)

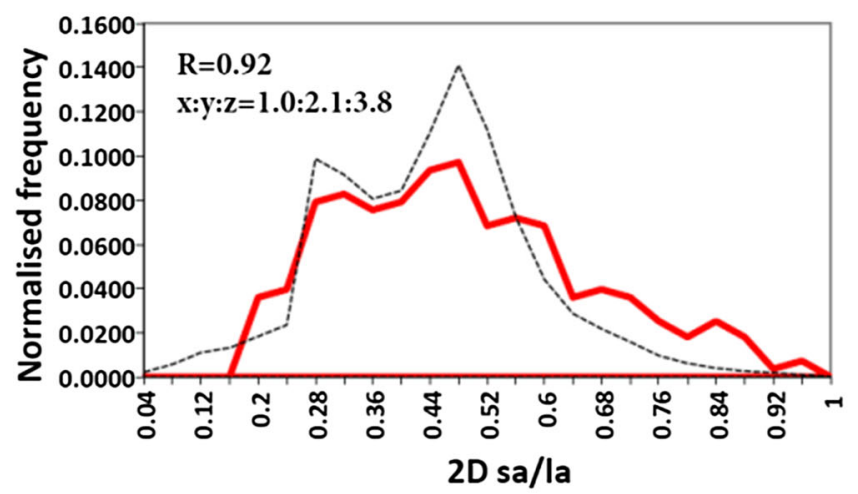

C Best fit shape curve of amphibolite (239/3A/3)
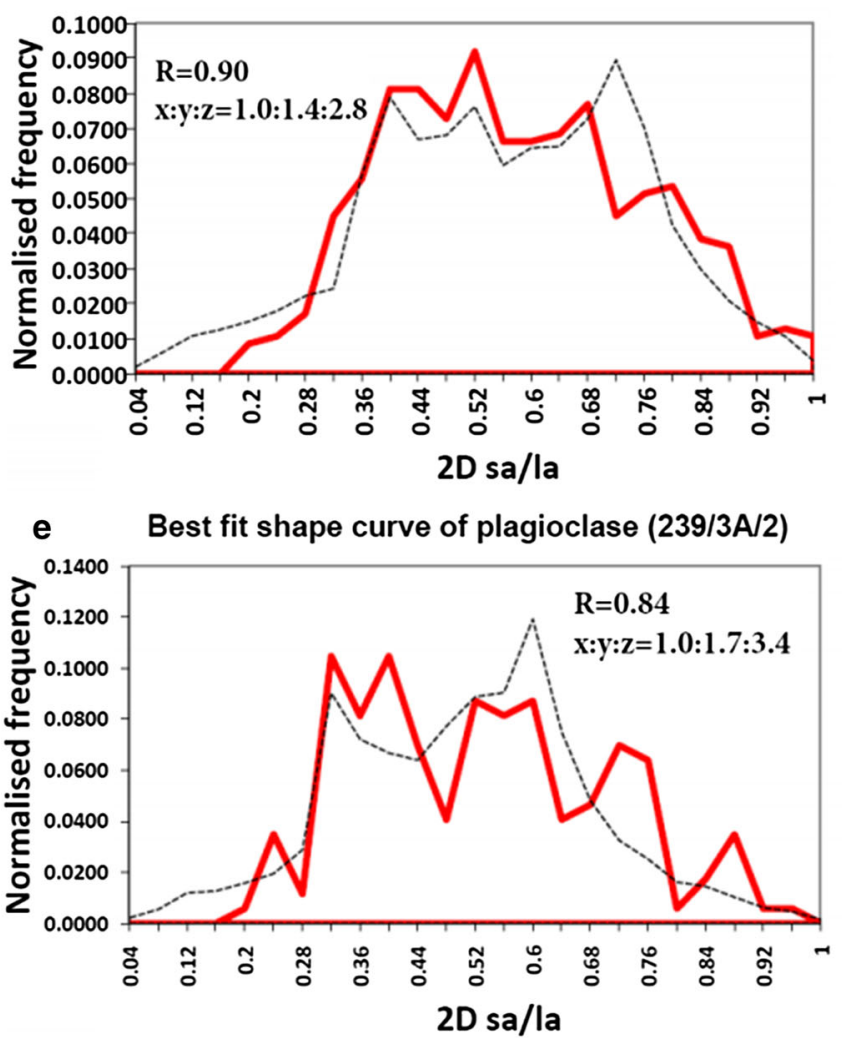

b Best fit shape curve of amphibolite (239/3A/2)

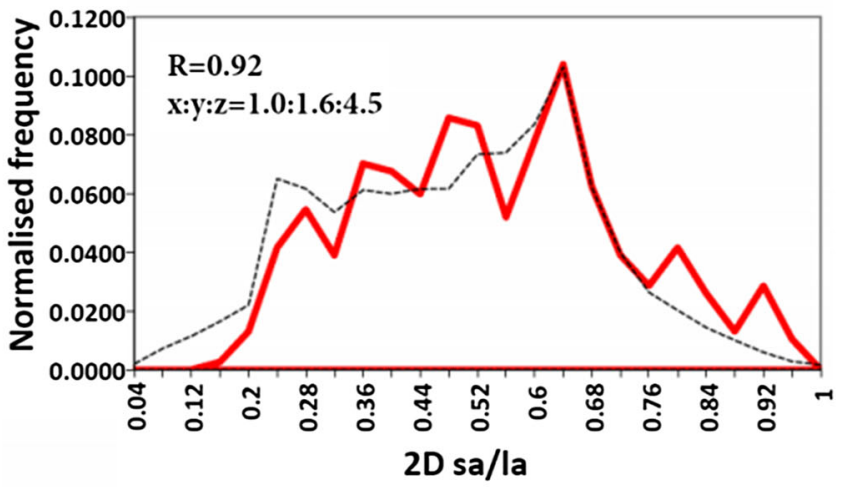

d Best fit shape curve of plagioclase (239/3A/1)

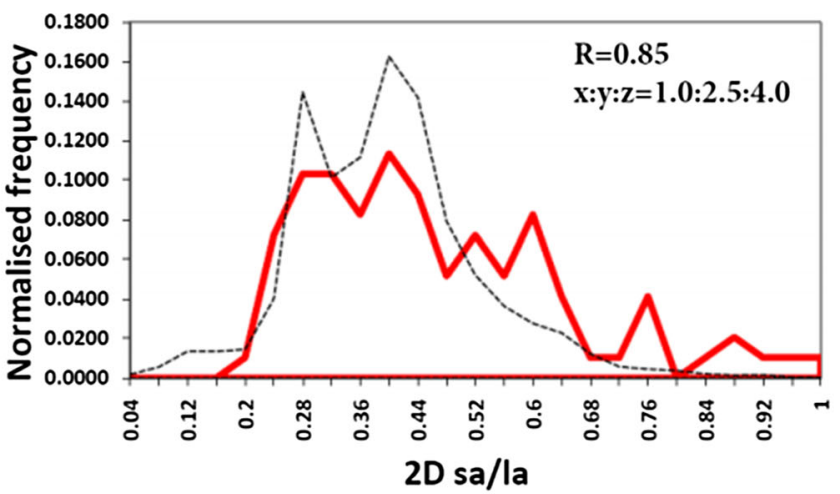

f Best fit shape curve of plagioclase (239/3A/3)

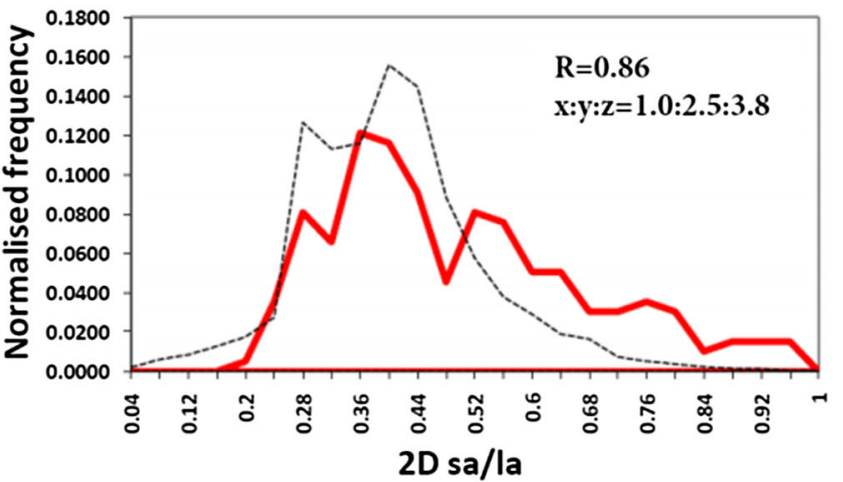

Figure 3. Best fit shape curve of hornblende $(\mathbf{a}-\mathbf{c})$ and plagioclase $(\mathbf{d}-\mathbf{f})$ of coarse grained mafic rocks of Bundelkhand Craton. Solid curves are calculated values which show how these fit with actual value (dotted curves). sa/la $=$ minor axis $/$ major axis of grains.

in two modes: (i) 'mafic clots' (figure 5d) and (ii) biotitized grains present along the boundary of feldspar grains. The foliation in foliated granite is marked by the preferred E-W alignment of mafic clots. This foliated granite contains slightly higher amount of titanite. In addition to wegde shaped titanite grains, titanite-plagioclase ocelli, titaniteplagioclase ophitic to sub-ophitic textures also occur (figure 5e). Hornblende grains also contain zircon inclusions (figure 5f).

\section{CSD result}

CSD analyses hornblende in mafic rocks show concave-up CSD with extremely insignificant fit to the straight line $(Q=5.3 \mathrm{E}-9$ to $1.3 \mathrm{E}-25$, table 3$)$. The CSDs show two distinct grain size populations (as marked by the dotted lines in figure $6 \mathrm{a}-\mathrm{c}$ ). The mean content or volumetric phase proportion (Higgins 2002) of hornblende in mafic rocks varies from 22.48 to $25.05 \%$ (figure $6 \mathrm{a}-\mathrm{c}$, table 1 ). 
CSD analyses of plagioclase in mafic rocks show significant fit to the straight line $(Q=0.21-0.54)$. The slope of the plagioclase CSDs in mafic rocks ranges from -0.846 to -1.23 , the characteristic length ranges from 0.813 to $1.18 \mathrm{~mm}$, and the intercept varies from -0.79 to -1.52 (table 3 ). The mean content or volumetric phase proportion (Higgins 2002) of plagioclase in mafic rocks ranges between 16.09 and $18.7 \%$ (table 1). Calculated residence time ranges $\sim 257-374$ yr (figure $6 \mathrm{~d}-\mathrm{f}$, table 3 ).

\section{Discussion and conclusion}

\subsection{Mingling effect of coeval felsic and mafic magmas: Field and petrographic evidence}

Interaction of coeval felsic and mafic magmas can lead to mixing, and mingling, depending on the viscosity and crystallinity of magma (Barbarin 2005). The effects of mingling/mixing of mafic magma and felsic magma produce some changes in outcrop and textural scale (Vernon 1990, 1991; Hibbard 1991; Baxter and Feely 2002). In outcrop, presence of cuspate-lobate contact indicates existence of two liquids when they came in contact (Barbarin and Didier 1992). The textures showing mingling and mixing effects are: (i) quartz ocelli (Vernon 1990, 1991; Hibbard 1991; Baxter and Feely 2002), (ii) rapakivi and/or antirapakivi texture (Hibbard 1991; Nekvasil 1991), (iii) poikilitic crystals of quartz and K-feldspars, titanite-plagioclase ocellar texture or ophitic relationship (Hibbard 1991; Baxter and Feely 2002), (iv) blade 'hydrogenic' biotite (Hibbard 1991; Vernon 2004), (v) inclusion zoned K-feldspar phenocrysts (Hibbard 1991; Vernon 2004; Słaby et al. 2007a, b; Vernon and Paterson 2008), (vi) anorthite spike zones in plagioclases (Wiebe 1968), (vii) acicular apatite and mixed apatite morphologies (Hibbard 1991; Baxter and Feely 2002) and small plagioclase laths (Hibbard 1991), (viii) K-feldspar megacrysts (Vernon 1991), (ix) mafic clots (Coats and Wilson 1971), and (x) resorbed phenocrysts (Gill 2010).

In the present area presence of cuspate-lobate boundary (figure $4 \mathrm{~b}$ and c) along the contact of granitoids and mafic rocks shows good evidence of magma mingling and their coeval emplacements. As mentioned earlier, the closure directions of the lobes vary from towards granitoids to towards the mafic rocks indicating comparable viscosities of the granitoids and mafic magma at the time of 

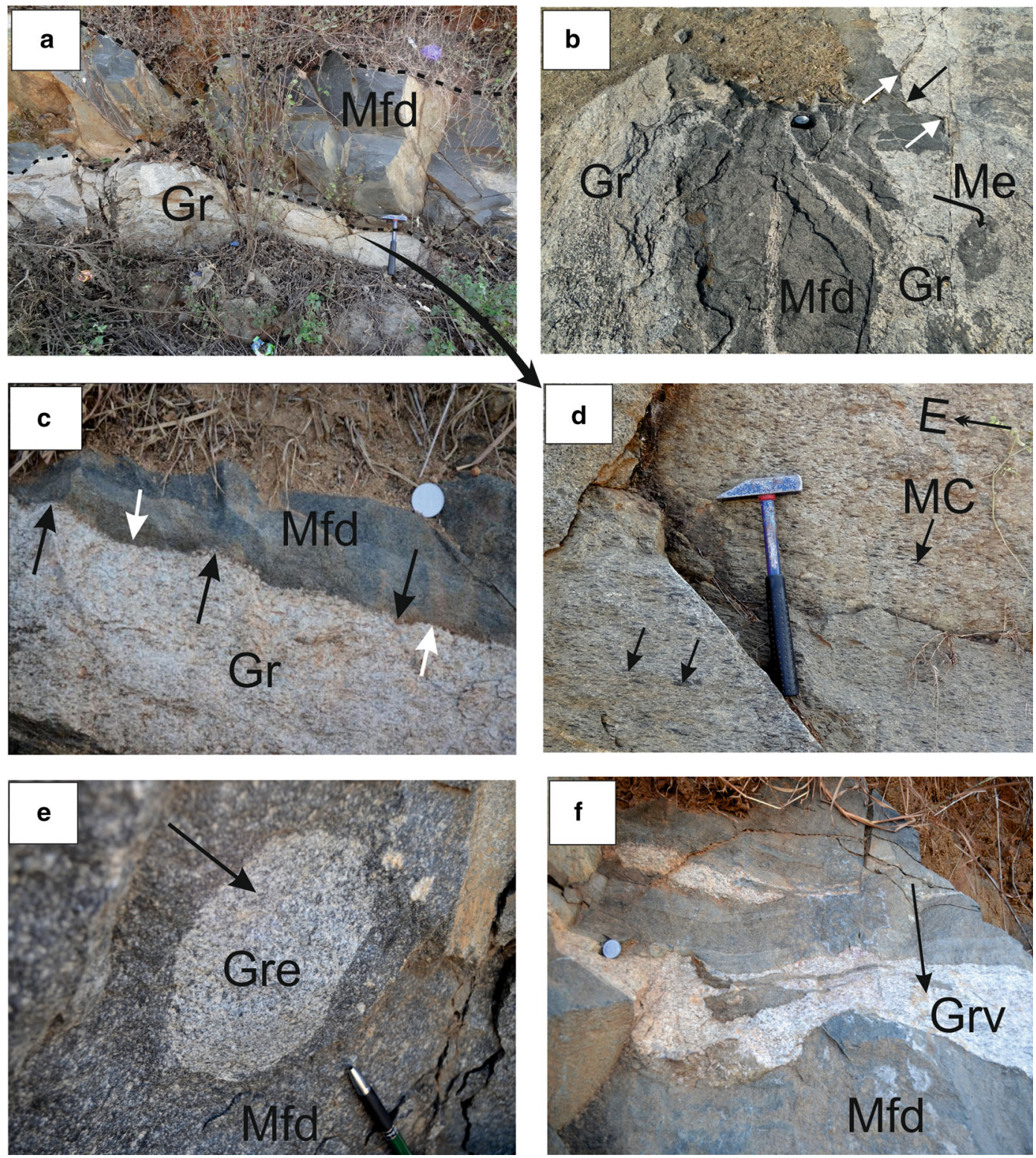

Figure 4. (a) Tabular fragment of syn-plutonic mafic dyke (Mfd) along the contact with foliated granitoids (FGr). (b) Mafic dyke (Mfd) present within medium grained granitoids ( Gr). Contact of mafic rock and granitoids show cuspatelobate contact (marked by the straight white and black arrows). Granitoids also contain enclaves of mafic rock (Me, marked by curved black arrow). (c) Cuspate-lobate contact along the granitoid and mafic boundary. Mafic rock shows lobate shape pointing towards granitoids (marked by the white arrows); granitoids show cuspate shape pointing towards mafic (marked by the black arrow) to the left side of the photograph and vice-versa to the right side of the photograph (marked by the arrows). (d) Field photo of foliated granitoids, showing E-W aligned mafic clots marked by single head arrow. (e) Mafic dyke with presence of elliptical granitoids enclaves (Gre, marked by black arrow). (f) Granitoids vein (Grv, marked by black arrow) occur within mafic rock.

mingling. This is also supported by the fact that the cusps are not sharp (figure 4c). Absence of any folding in granitoids and mafic rocks indicates this cuspate-lobate form along their contact is formed due to magma mingling, and not due to compression. Elliptical enclaves of mafic rocks in granitoids and vice versa (figure $4 \mathrm{~b}$, e) also imply both were in still liquid state while mingling. Under the microscope, the presence of mafic clots (figures $4 \mathrm{~d}$ and $5 \mathrm{~d}$ ) in the foliated (type-i) granitoid zone (present along the contact of mafic rock) suggests that mafic clots have originated in mafic magma and interaction with granitoid melt near the boundary brought the blebs (later converted to clots) into the granitoid part. Preferred E-W orientation of these mafic clots indicates that shearing 

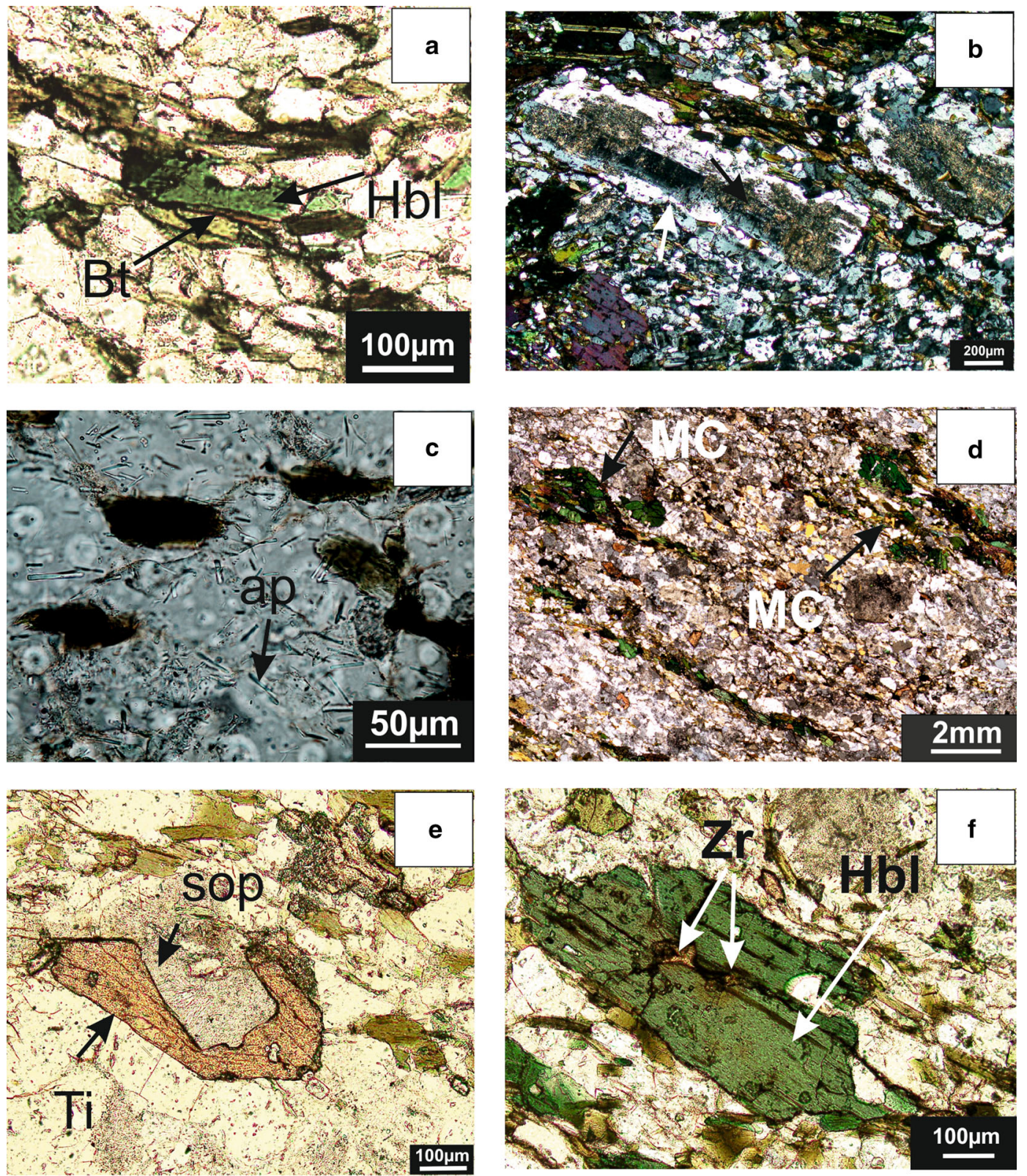

Figure 5. Photomicrographs showing (a) composite grain of hornblende (hbl) and biotite (bt). (b) Sericitized (marked by black arrow) plagioclase with resorbed boundary (marked by the white arrow). (c) Inclusions of randomly oriented apatite needles (ap) in feldspar grains of coarse grained mafic rocks. (d) Presence of E-W aligned 'mafic clots' (MC) in foliated granitoids which occur near the boundary with mafic rocks. (e) Titanite-plagioclase sub-ophitic (sop) relationship in foliated granitoids present near the boundary with the mafic rocks. (f) Hornblende (Hbl) with zircon (Zr) inclusion.

was continuing during mingling. Quenching is responsible for the formation of acicular apatite (cf. Hibbard 1991) in mafic and foliated granitoid rocks. Hotter mafic magma cooled very rapidly when came in contact with cooler granitoid magma producing such acicular apatite. Abundance of apatite needles in mafic and foliated (type-i) granitoid indicated rapid thermal exchange between mafic magma and granitic magma during their interaction (figure 5c). Titanite-plagioclase ophitic and sub-ophitic relationships (figure 5e) are also interpreted as the result of magma mingling (cf. Hibbard 1991; Baxter and Feely 2002). Undercooling of mafic magma prompted crystallization of plagioclase and titanite with ophitic relationship during early mixing (Baxter and Feely 2002). Hibbard (1991) interpreted that this is a very common texture in more mafic part. However, in Bundelkhand in addition to the mafic part, this texture is also common in foliated (type-i) granitoids near the mafic rock inclusions. This may indicate thermal exchange between granitoid 
Table 3. Crystal size distribution parameters of hornblende and plagioclase of coarse grained mafic rocks of Bundelkhand Craton.

\begin{tabular}{|c|c|c|c|c|c|}
\hline $\begin{array}{l}\text { Minerals in mafic } \\
\text { rocks and slide no. }\end{array}$ & $\begin{array}{l}\text { Goodness } \\
\text { of fit }(Q)\end{array}$ & $\begin{array}{l}\text { Intercept } \\
\text { (proportional to } \\
\text { nucleation density) }\end{array}$ & Slope & $\begin{array}{l}\text { Characteristic } \\
\text { length in mm } \\
(-1 / \text { slope })\end{array}$ & $\begin{array}{l}\text { Residence } \\
\text { time } \\
\text { (year) }\end{array}$ \\
\hline Hornblende $(239 / 3 \mathrm{~A} / 1)$ & $5.3 \mathrm{E}-9$ & - & - & - & - \\
\hline Hornblende $(239 / 3 \mathrm{~A} / 2)$ & $5.42 \mathrm{E}-15$ & - & - & - & - \\
\hline Hornblende $(239 / 3 \mathrm{~A} / 3)$ & $1.3 \mathrm{E}-25$ & - & - & - & - \\
\hline Plagioclase (239/3A/1) & 0.54 & -0.79 & -1.23 & 0.813 & 257.8 \\
\hline Plagioclase $(239 / 3 \mathrm{~A} / 2)$ & 0.32 & -1.52 & -0.846 & 1.18 & 374.8 \\
\hline Plagioclase $(239 / 3 \mathrm{~A} / 3)$ & 0.12 & -0.72 & -1.12 & 0.892 & 283.1 \\
\hline
\end{tabular}
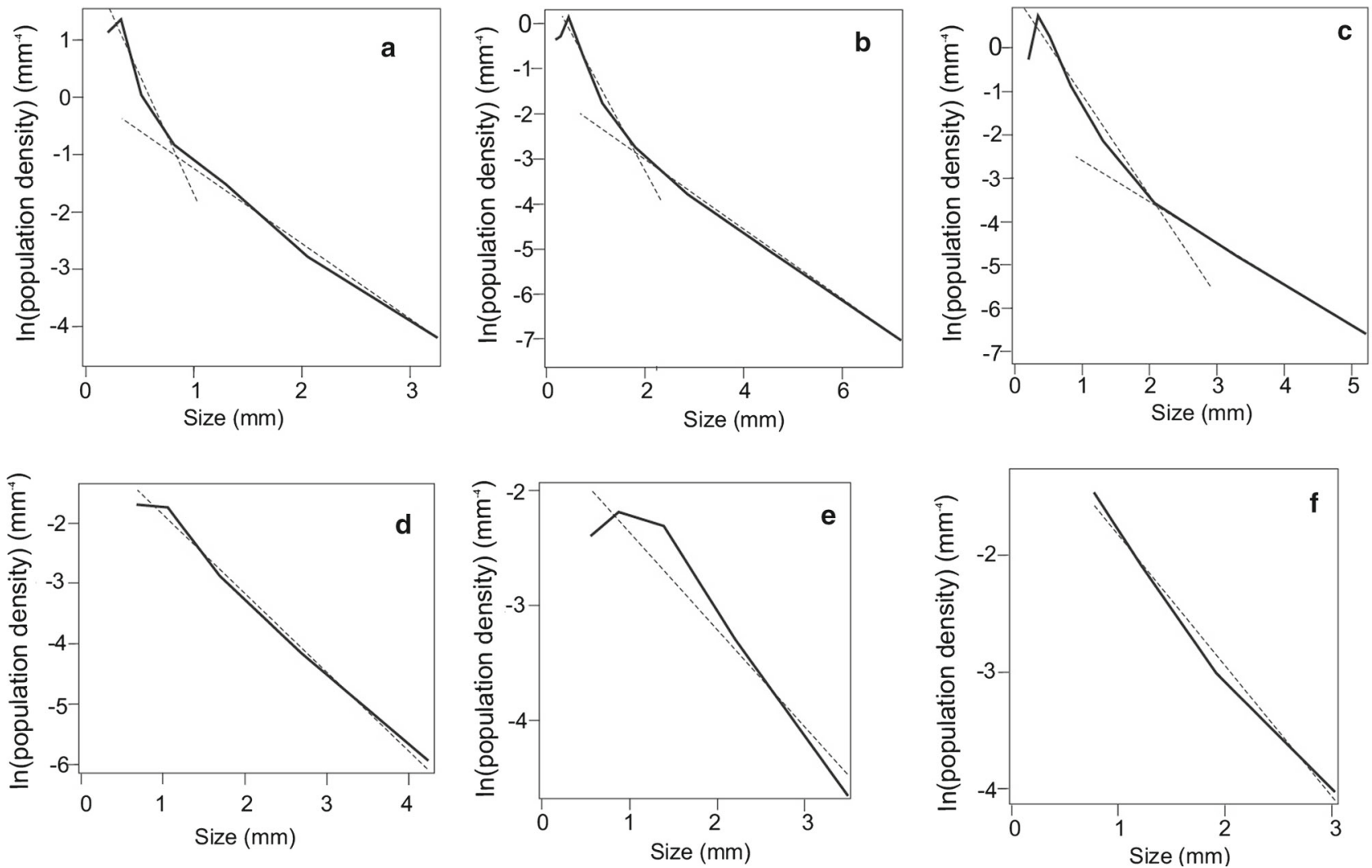

Figure 6. Crystal size distribution study of hornblende $(\mathbf{a}-\mathbf{c})$ and plagioclase $(\mathbf{d}-\mathbf{f})$ of coarse grained mafic rocks. Dotted lines indicate best fit lines.

magma and mafic magma along the contact. Resorption textures in plagioclase are often interpreted as changes in plagioclase stability, caused due to mixing process (Hibbard 1981; Elangovan et al. 2017). Plagioclase grains in mafic as well as in granitoids show resorbed boundary suggesting the occurrence of magma mingling (figure 5b). Abundance of zircon inclusions within hornblende grains (figure 5f) in foliated granitoids near mafic inclusions also implies fluid activity along the contact (cf. Seaman and Ramsay 1992). However, mafic magma contain less volatile matter (i.e., water) than granitoids, and this fluid tends to move from the hotter mafic to cooler, crystallizing granitoid magma while mingling. Zirconium ions are more soluble in higher temperature mafic magma than cooler granitoid magma (Watson and Harrison 1983; Seaman and Ramsay 1992). Fluid migrated from the mafic part also carried the zirconium ions to the surrounding foliated granitoids. Cooler granitoid melts are suitable for crystallization of zircon. Fluid carrying the zirconium ions outside the mafic enclaves may be also providing the water necessary for hornblende crystal to form. 
Thus, the field and textural observations strongly suggest a scenario of mingling of mafic magma with granitoid magma. The mafic magma intruded as dykes the granitoid body in its late stage of crystallization, and formed syn-plutonic mafic dykes (cf. Jayananda et al. 2014; Elangovan et al. 2017). These dykes got fragmented due to movements within the highly viscous granitoid body and formed the tabular fragments.

\subsection{Mingling effect of coeval felsic and mafic magmas: Crystal size distribution evidences}

Crystal size distribution is another important technique to understand magma chamber dynamics, magma residence, and mixing event (Marsh 1988, 1998). Marsh (1988) proposed a model which describes the crystal population of steady-state open magmatic system, i.e., a magma chamber which is continuously fed with new magma and drained by eruptions. The CSD in such a magma chamber is described by a straight line with negative slope when plotted on natural logarithm of population density vs. length graph. Presence of one straight line in CSD graph implies constant condition. A decrease in temperature produces a series of straight lines with same slope, but different intercepts (Higgins 2006). Higgins (2006) also proposed that a longer residence time produces a change in the CSD slope, but with the same intercept. Crystal accumulation produced gentler slope as the larger crystals descend faster than the smaller ones whereas crystal fractionation produced steeper slope because of removal of larger crystals (Marsh 1988; Higgins 2002). The strongly curved concave up CSD is produced due to mixing of magmas (Higgins 1996). However, curved CSD is also produced by sequential period of cooling during the ascent and emplacement of magma (Armienti et al. 1994). Ostwald ripening (or coarsening) is another important process for plutonic as well as volcanic rocks (Higgins 1998; Higgins and Roberge 2003, 2007). Hump-shaped CSD is produced in metamorphic rocks (Casman and Ferry 1988). However, coarsening also produces either hump shaped CSD or right side flattened and left side downward kinking in CSD (Higgins 1998). Coarsening also involves shallow slope in CSD with large maximum size (Higgins and Roberge 2007).

However, plagioclase laths of coarse grained mafic rocks produce a nearly straight linear CSD with significant fit (figure $6 \mathrm{~d}-\mathrm{f}$ ). On the contrary, strongly curved CSD of hornblende grains suggested interaction of mafic and felsic magma. Curved CSDs of hornblende show two distinct grain sized populations which may be formed by thermal exchange (figure $6 \mathrm{a}-\mathrm{c}$ ). Hot mafic magma came in contact with a relatively cold felsic magma resulting in undercooling of the mafic magma and induced rapid crystallization. This led to the formation of small grain size due to higher nucleation rate of crystals while large grain size population formed later when thermal exchange became less significant. CSD of hornblende also retained the signature of magma mingling.

From the above, we conclude:

- Occurrence of granitoid enclaves within mafic rocks and vice versa, cuspate-lobate contact of granitoids and mafic rocks suggest coeval emplacement of felsic and mafic magmas.

- Abundance of apatite needles in mafic rocks and in foliated granitoid near the mafic bodies implies rapid thermal exchange while mingling.

- Abundance of zircon in some hornblende in the foliated granitoid indicates fluid activity along contact.

- Curve CSD of hornblende in mafic rock implies interaction (thermal exchange) of felsic and mafic magmas in Bundelkhand Craton.

- All these suggest that the mingling took place during the emplacement of mafic magma as syn-plutonic dykes within a still crystallizing granitoid body.

\section{Acknowledgements}

Deb would like to thank Dr Abdul Matin for his help during fieldwork and Dr Dougal Jerram for providing CSD slice software. Authors also acknowledge Dr M D Higgins for the CSD Correction software. Authors are thankful to the Department of Geology, University of Calcutta for providing the laboratory support. Deb's work is supported by UGC-RFSMS, University Grant Commission, India and this work is a part of her Ph.D. The authors acknowledge the two anonymous reviewers for their very helpful comments on an earlier version of the paper.

\section{References}

Armienti P, Pareschi M T, Innocenti F and Pompilio M 1994 Effects of magma storage and ascent on the kinetics of crystal growth; Contrib. Mineral. Petrol. 115 402-414. 
Barbarin B 2005 Mafic magmatic enclaves and mafic rocks associated with some granitoids of the central Sierra Nevada batholiths California nature origin and relations with the hosts; Lithos 80 155-177.

Barbarin B and Didier J 1991 Review of the main hypothesis proposed for the genesis and evolution of mafic microgranular enclaves; Enclaves and Granite Petrology 13 367-373.

Barbarin B and Didier J 1992 Genesis and evolution of mafic microgranular enclaves through various types of interaction between coexisting felsic and mafic magmas; Trans. Roy. Soc. Edinb. Earth Sci. 83 145-153.

Basu A K 1986 Geology of Bundelkhand Granite massif Central India; Record, GSI 117(2) 61-124.

Baxter S and Feely M 2002 Magma mixing and mingling textures in granitoids examples from the Galway Granite Connemara Ireland; Mineral. Petrol. 76 63-74.

Bhattacharya A R and Singh S P 2013 Proterozoic crustal scale shearing in the Bundelkhand massif with special reference to Quartz Reefs; J. Geol. Soc. India 82 474-484.

Burda J, Gawęda A and Klotzli U 2011 Magma hybridization in the Western Tatra Mts granitoid intrusion (S-Poland, Western Carpathians); Mineral. Petrol. 103 19-36.

Cashman K V 1993 Relationship between plagioclase crystallization and cooling rate in basaltic melts; Contrib. Mineral. Petrol. 113 126-142.

Cashman K V and Ferry J M 1988 Crystal size distribution technique to identify the growth mechanisms response (CSD) in rocks and the kinetics and dynamics of crystallisable for the observed zoning patterns in the zoned action. III. Metamorphic crystallization; Contrib. Mineral. Petrol. 99 401-415.

Cashman K V and Marsh B D 1988 Crystal size distribution (CSD) in rocks and the kinetics and dynamics of crystallization: II. Makaopuhi lava lake; Contrib. Mineral. Petrol. $99292-305$.

Coats J S and Wilson J R 1971 The eastern end of the Galway Granite; Mineral. Mag. 38 138-151.

Eberl D D, Drits V A and Srodon J 1998 Deducing growth mechanism for minerals from the shape of crystal size distribution; Am. J. Sci. 298 499-553.

Elangovan R, Krishna K, Vishwakarma N, Hari K R and Ram Mohan M 2017 Interaction of coeval felsic and mafic magmas from the Kanker granite, Pithora region, Bastar Craton, central India; J. Earth Syst. Sci. 126(7) ID 92.

Frost T P and Mahood G A 1987 Field chemical and physical constraints on mafic-felsic magma interaction in the Lamarck Granodiorite Sierra Nevada California; Geol. Soc. Am. Bull. 99 272-291.

Gill R 2010 Igneous rocks and processes; A practical guide; John Wiley \& Sons, Ltd.

Gupta A 2004 A manual of the geology of India; GSI Special Publication, Kolkata $\mathbf{7 7 .}$

Hibbard M J 1981 The magma mixing origin of mantled feldspars; Contrib. Mineral. Petrol. 76 158-170.

Hibbard M J 1991 Textural anatomy of twelve magma-mixed granitoid systems; In: Enclaves and granite petrology (eds) Didier J and Barbarin B, Elsevier Amsterdam, pp. 431444.

Higgins M D 1996 Crystal size distributions and other quantitative textural measurements in lavas and tuff from Mt. Taranaki (Egmont volcano), New Zealand; Bull. Volcanol. 58 194-204.
Higgins M D 1998 Origin of anorthosite by textural coarsening: Quantitative measurements of a natural sequence of textural development; J. Petrol. 39 1307-1325.

Higgins M D 2000 Measurement of crystal size distributions; Am. Mineral. 85 1105-1116.

Higgins M D 2002 Closure in crystal size distributions (CSD), verification of CSD calculations, and the significance of CSD fans; Am. Mineral. 87 171- 175.

Higgins M D 2006 Verification of ideal semi-logarithmic, lognormal or fractal crystal size distributions from $2 \mathrm{D}$ datasets; J. Volcanol. Geotherm. Res. 154 8-16.

Higgins M D and Roberge J 2003 Crystal size distribution (CSD) of plagioclase and amphibole from Soufriere Hills volcano, Montserrat: Evidence for dynamic crystallisation/textural coarsening cycles; J. Petrol. 44 1401-1411.

Higgins M D and Roberge J 2007 Three magmatic components in the 1973 eruption of Eldfell volcano, Iceland: Evidence from plagioclase crystal size distribution (CSD) and geochemistry; J. Volcanol. Geotherm. Res. 161(3) $247-260$.

Jayananda M, Gireesh R, Sekhamo K-U and Miyazaki T 2014 Coeval felsic and mafic magmas in neoarchean calcalkaline magmatic arcs, Dharwar craton, southern India: Field and petrographic evidence from mafic to hybrid magmatic enclaves and synplutonic mafic dykes; J. Geol. Soc. India 84 5-28.

Jerram D A, Cheadle M C and Philpotts A R 2003 Quantifying the building blocks of igneous rocks: Are clustered crystal frameworks the foundation? J. Petrol. 442033 2051.

Kumar S 2010 Mafic to hybrid microgranular enclaves in the Ladakh batholith, northwest Himalaya: Implications on calc-alkaline magma chamber processes; J. Geol. Soc. India 76 5-25.

Kumar S, Raju S, Pathak M and Pandey A 2010 Magnetic susceptibility mapping of felsic magmatic lithounit in the central part of Bundelkhand Massif Central India; J. Geol. Soc. India 75 539-548.

Kumar S, Bora S, Raju S, Yi K, Pathak M, Kim N and Lee T H 2013 Crustal evolution of Bundelkhand Craton: Constrains from whole rock geochemistry and $\mathrm{U}-\mathrm{Pb}$ SHRIMP Zircon Chronology; In: International Association for Gondwana Research Conference Series No. 16 (eds) Singh V K and Chandra R, 3rd International Conference Precambrian Continental Growth and Tectonism Jhansi, pp. 89-90.

Lai Y M, Song S R and Iizuka Y 2008 Magma mingling in the Tungho area, Coastal Range of eastern Taiwan; J. Volcanol. Geotherm. Res. 178 608-623.

Malviya V P, Arima M, Pati J K and Kaneko Y 2006 Petrology and geochemistry of metamorphosed basaltic pillow lava and basaltic komatiite in Mouranipur area: Subduction related volcanism in the Archean Bundelkhand craton, central India; J. Mineral. Petrol. Sci. 101199 217.

Marsh B D 1988 Crystal size distribution (CSD) in rocks and the kinetics and dynamics of crystallization I Theory; Contrib. Mineral. Petrol. 99 277-291.

Marsh B D 1998 On the interpretation of crystal size distributions in magmatic systems; J. Petrol. 39 553-600.

Mondal M E A and Zainuddin S A 1996 Evolution of Archean-Palaeoproterozoic Bundelkhand massif, central 
India - evidence from granitiod geochemistry; Terra Nova $8532-539$.

Morgan D J and Jerram D A 2006 On estimating crystal shape for crystal size distribution analysis; J. Volcanol. Geotherm. Res. 154 1-7.

Morgan D J, Jerram D A, Chertkoff D G, Davidson J P, Pearson D G, Kronz A and Nowell G M 2007 Combining CSD and isotopic microanalysis: Magma supply and mixing processes at Stromboli Volcano, Aeolian Islands Italy; Earth Planet. Sci. Lett. 260 419-431.

Nekvasil H 1991 Ascent of felsic magmas and formation of rapakiv; Am. Mineral. 76 1279-1290.

Neves S P and Vauchez A 1995 Successive mixing and mingling of magmas in a plutonic complex of northeast Brazil; Lithos 34 275-299.

Pabst A 1928 Observations on inclusions in the granitic rocks of the Sierra Nevada; Univ. Calif. Publ. Geol. Sci. 17 325386.

Pati J K, Patel S C, Pruseth K L, Malviya V P, Arima M, Raju S, Pati P and Prakash K 2007 Geology and geochemistry of giant quartz veins from the Bundelkhnad Craton, central India and their implications; J. Earth Syst. Sci. $116497-510$.

Pradhan V R, Meert J G, Pandit M K, Kamenov G and Mondal M E A 2012 Paleomagnetic and geochronological studies of the mafic dyke swarms of Bundelkhand craton, central India: Implications for the tectonic evolution and paleogeographic reconstructions; Precamb. Res. 198-199 $51-76$.

Prakash K, Mohanty T, Chube K and Prakash P 2013 Characterization and Spatial Distribution of Quartz Reefs in Archean Bundelkhand Craton Based on Remote Sensing Data and their implications; Int. J. Basic Appl. Sci. 2 $48-52$.

Ramkrishnan M and Vaidyanadhan R 2008 Geology of India; Geological society of India, Bangalore 1 249-260.

Ramiz M M and Mondal M E A 2017 Petrogenesis of mafic magmatic enclaves of the Bundelkhand granitoids near Orccha, Central Indian shield: Evidence for rapid crystallization; In: Crust mantle interactions and granitoid diversification: Insights from Archaean Cratons (eds) Halla J, Whitehouse M J, Ahmad T and Bagai Z; Geol. Soc, London Spec. Publ. 449.

Ram Mohan M, Singh S P, Santosh M, Siddique M A and Balaram V 2012 TTG suite from the Bundelkhand Craton Central India: Geochemistry, petrogenesis and implications for Archean Crustal Evolution; J. Asian Earth Sci. $5838-50$.

Rao J M, Rao G V S P, Widdowson M and Kelley S P 2005 Evolution of Proterozoic mafic dyke swarms of the Bundelkhand Granite Massif central India; Curr. Sci. 88 502-506.

Ray L, Nagaraju P, Singh S P, Ravi G and Roy S 2015 Radioelemental petrological and geochemical characterization of the Bundelkhand craton, central India: Implication in the Archaean geodynamic evolution; Int. J. Earth Sci., https://doi.org/10.1007/s00531-015-1229-4.
Seaman S J and Ramsay P C 1992 Effects of Magma Mingling in the Granites of Mount Desert Island, Maine; J. Petrol. 100 395-409.

Sharma R P 1982 Lithostratigraphy, structure and petrology of the Bundelkhand Group; In: Geology of Vindhyachal (eds) K S Valdiya, S S Bhatia and V K Gaur; Hind Publ. Corp. Delhi, pp. 30-46.

Sharma K K and Rahman A 1995 Occurrence and petrogenesis of Loda Pahar trondhjemitic gneiss from Bundelkhand Craton, central India: Remnant of anearly crust; Curr. Sci. 69 613-616.

Singh V K and Salbunov A 2015 The Central Bundelkhand Archaean greenstone complex, Bundelkhand craton, central India: Geology, composition, and geochronology of supracrustal rocks; Int. Geol. Rev. 57 13491364 .

Sklyarov E V and Fedorovsky V S 2006 Magma mingling: Tectonic and geodynamic aspects; Geotektonika $\mathbf{2}$ 47-64.

Słaby E and Götze J 2004 Feldspar crystallization under magma-mixing conditions shown by cathodoluminescence and geochemical modelling - a case study from the Karkonosze pluton (SW Poland); Miner. Mag. 68 541557.

Słaby E, Galbarczyk-Gạsiorowska L, Seltmann R and Müller A 2007a Alkali feldspar megacryst growth: Geochemical modelling; Mineral. Petrol. 89 1-29.

Słaby E, Seltmann R, Kober B, Müller A, GalbarczykGassiorowska L and Jeffries T 2007b LREE distribution patterns in zoned alkali feldspar megacrysts - implication for parental melt composition; Miner. Mag. 71 193217.

Vernon R H 1984 Microgranitoid enclaves: Globules of hybrid magma quenched in a plutonic environment; Nature 304 438-439.

Vernon R H 1990 Crystallisation and hybridism in microgranitoid enclave magmas: Microstructural evidence; J. Geophys. Res. 95(B11) 17,849-17,859.

Vernon R H 1991 Interpretation of microstructures of microgranitoid enclaves; In: Enclaves and granite petrology (eds) Didier J and Barbarin B, Elsevier, Amsterdam, pp. 277-292.

Vernon R H 2004 A practical guide to rock microstructure, Chapter 3; Cambridge University Press.

Vernon R H and Paterson S R 2008 How late are K-feldspar megacrysts in granites? Lithos 104 327-336.

Watson E B and Harrison T M 1983 Zircon saturation revisited: Temperature and composition effects in a variety of crystal magma types; Earth Planet Sci. Lett. 64 295304 .

Wiebe R A 1968 Plagioclase stratigraphy: A record of magmatic conditions and events in A granite stock; Am. J. Sci. 266 690-703.

Wilcox R E 1999 The idea of magma mixing: History of a struggle for acceptance; J. Geol. 107 421-432.

Winter J D 2010 Principal of igneous and metamorphic petrology; Pearson Education, Inc., London. 